NBER WORKING PAPER SERIES

\title{
WAS IT PRICES, PRODUCTIVITY OR POLICY? THE TIMING AND PACE OF LATIN AMERICAN INDUSTRIALIZATION AFTER 1870
}

\author{
Aurora Gómez Galvarriato \\ Jeffrey G. Williamson \\ Working Paper 13990 \\ http://www.nber.org/papers/w13990
NATIONAL BUREAU OF ECONOMIC RESEARCH
1050 Massachusetts Avenue
Cambridge, MA 02138

May 2008

\begin{abstract}
We are grateful for the excellent research assistance supplied by Taylor Owings, Rodrigo Parral, Abdallah Salam, and Carolyn Sheehan. We have also benefited from help with the data, useful advice and criticism offered by Ted Beatty, Luis Bértola, Luis Catão, John Coatsworth, Rafa Dobado, Zephyr Frank, Steve Haber, Adolfo Meisel, Aldo Musacchio, Graciela Márquez, Noel Maurer, José Antonio Ocampo, Leandro Prados, Maria Teresa Ribeiro de Oliveira, Dick Salvucci, Alan Taylor and Miguel Urrutia. Williamson acknowledges with pleasure financial support from the Harvard Faculty of Arts and Sciences. The views expressed herein are those of the author(s) and do not necessarily reflect the views of the National Bureau of Economic Research.
\end{abstract}

NBER working papers are circulated for discussion and comment purposes. They have not been peerreviewed or been subject to the review by the NBER Board of Directors that accompanies official NBER publications.

(C) 2008 by Aurora Gómez Galvarriato and Jeffrey G. Williamson. All rights reserved. Short sections of text, not to exceed two paragraphs, may be quoted without explicit permission provided that full credit, including $\odot$ notice, is given to the source. 
Was It Prices, Productivity or Policy? The Timing and Pace of Latin American Industrialization after 1870

Aurora Gómez Galvarriato and Jeffrey G. Williamson

NBER Working Paper No. 13990

May 2008

JEL No. F1,N7,O2

\begin{abstract}
Brazil, Mexico and a few other Latin American republics enjoyed faster industrialization after 1870 than did the rest of Latin America and even faster than the rest of the poor periphery (except East Asia). How much of this economic performance was due to more accommodating institutions and greater political stability, changes that would have facilitated greater technology transfer and accumulation? That is, how much to changing fundamentals? How much instead to a cessation in the secular rise in the net barter terms of trade which reversed de-industrialization forces, thus favoring manufacturing? How much instead to cheaper foodstuffs coming from more open commercial policies ('grain invasions'), and from railroad-induced integration of domestic grain markets, serving to keep urban grain prices and thus nominal wages in industry low, helping to maintain competitiveness? How much instead to more pro-industrial real exchange rate and tariff policy? Which of these forces contributed most to industrialization among the Latin American leaders, long before their mid 20th century adoption of ISI policies? Changing fundamentals, changing market conditions, or changing policies?
\end{abstract}

\author{
Aurora Gómez Galvarriato \\ Division of Economics CIDE \\ Lomas de Sta. Santa Fe 12010 \\ Mexico D.F. Mexico \\ aurora.gomez@amadeus.cide.edu \\ Jeffrey G. Williamson \\ Department of Economics \\ Harvard University and CEPR \\ Cambridge MA 02138 USA \\ and NBER \\ jwilliam@fas.harvard.edu
}




\section{On Being Misled: Prebisch, Singer and the Terms of Trade Debate}

Debate over trends in the terms of trade between primary products and manufactures, their causes and their impact has dominated the growth and development literature for almost two centuries. Classical economists claimed that the relative price of primary products should improve over time, since land and other natural resources were in inelastic supply while capital and labor were not. The experience over the half century or so before the 1870 s proved them right: the relative price of manufactures underwent a spectacular decline, while that of primary products soared (Figure 5). In the early 1950s, however, Raúl Prebisch (1950) and Hans Singer (1950) challenged the classical view, asserting that the terms of trade of the primary-productproducing Third World had deteriorated since the late $19^{\text {th }}$ century. Indeed, Prebisch calculated that only 63 percent of the finished manufactures which could be bought with a given quantity of primary products in the 1860 s could be purchased in the 1930s. Prebisch and Singer also predicted that it would continue to deteriorate across the late $20^{\text {th }}$ century as long as the Third World specialized in primary products. It turned out that their prediction was not confirmed, ${ }^{1}$ but our interest lies instead with the years from about 1870 to World War I, an era in which W. Arthur Lewis' (1978) new world economic order - the rich core specializing in manufactures and the poor periphery in primary products -- was being challenged in some parts of the periphery.

This important part of the development literature has its shortcomings. ${ }^{2}$ While the pre1870 s secular upswing of the terms of trade in the periphery clearly caused de-industrialization there (Williamson 2006a, 2006b, 2008), Prebisch, Singer and their followers ignored a symmetric corollary: on the downside following the 1870 s, the secular terms of trade deterioration implied a long run stimulus to import-competing industry in the periphery. Prebisch and Singer ignored this

\footnotetext{
${ }^{1}$ The relative price of primary products did not deteriorate over the late $20^{\text {th }}$ century (Grilli and Yang 1988; Blattman, Hwang and Williamson 2006), and by the end of the century most of the Third World exported labor-intensive manufactures (Martin 2003; Williamson 2006b).

${ }^{2}$ Although now more than 15 years old, a paper by Roberto Cortés Conde (1992) is still one of the best surveys of export-led growth and dependency paradigms as applied to Latin America for this period.
} 
possibility, ${ }^{3}$ and stressed instead the short run economic damage to a periphery specializing in primary products. The literature generated by Prebisch and Singer has another weakness:

typically, it deals with the relative price of primary products in world markets, not with the terms of trade facing any given primary-product exporting country. Prebisch, Singer and the literature that followed never assessed the economic impact on the poor periphery of the secular fall, or of a cessation of the rise, in its terms of trade. Rather, they assumed it.

We try to do better when assessing Latin American industrialization experience after 1870 , those critical decades before the interwar economic disaster, and before the introduction of anti-global ISI policies between the 1930s and 1970s. Furthermore, our interest is in the relative industrial performance around Latin America. In addition, we try to assess the relative contribution of world prices on Latin American performance compared with other domestic forces. Section 2 establishes the timing and pace of Latin American industrialization, with primary focus on the leaders - especially Brazil and Mexico. Industrialization was fast in some of those places, especially when compared with the rest of Latin America, Asia and the Middle East. Section 3 lists the leading explanations, not necessarily competing, for this impressive industrialization performance - changing world prices, changing productivity, changing policy and changing wage competitiveness. Section 4 explores the first, a dramatic change in net barter terms of trade $\left(\mathrm{P}_{\mathrm{X}} / \mathrm{P}_{\mathrm{M}}\right)$ trends in much of Latin America, especially compared with the rest of the periphery. We argue that if, as the conventional literature asserts, a rise in the net barter terms of trade caused de-industrialization in the periphery prior to 1870 (through Dutch disease effects), then its stability or fall thereafter must have helped cause what might be called reindustrialization. Section 5 explores a part of the second explanation -- an acceleration in total factor productivity growth in the export sector, especially mining. The latter should have raised

\footnotetext{
${ }^{3}$ Not entirely, since at one point in his famous 1950 paper Singer noted that if the post-1950 relative price of primary products ever did improve, it would reduce industrialization incentives in the periphery (Singer 1950: 482, italics added). However, Singer never elaborated on this statement, either in the 1950 paper or elsewhere. Nor did Prebisch. Nor did their followers.
} 
the income terms of trade $\left(\mathrm{P}_{\mathrm{X}} \mathrm{X} / \mathrm{P}_{\mathrm{M}}\right)$, and, as Edward Beatty (2000) has argued so persuasively for Mexico, it should have contributed to export-led industrialization. We ask whether Mexican experience was exceptional, or whether it was repeated in other Latin American industrial leaders. Section 6 searches for other sources of Latin America's increasing industrial competitiveness in their own markets - like cheaper food keeping the nominal industrial wage low. Section 7 explores the impact of real exchange rate depreciation, a force that would have improved local manufacturing competitiveness against foreign imports. Section 8 concludes with an agenda and a tentative judgment about the relative importance of changes in prices, policies and fundamentals.

\section{Measuring the Industrial Liftoff Across Latin America}

We are not the first to argue that industrialization started long before the 1930s in Latin America, indeed, even before World War I. Ezequiel Gallo (1970) made the case for Argentina back when dependency theory and export-led growth were the dominant paradigms. Warren Dean (1969) did the same for Brazil about the same time. Two decades later, Steve Haber $(1989,1990)$ made the same case for Mexico. While impressive, what is missing from this pioneering literature is an explicit comparative assessment of the timing and the pace of industrialization in Latin America, and a comprehensive assessment of its causes. We begin to fill that gap here.

Whether measured by employment, output or value added, textile production dominated manufacturing in the late $19^{\text {th }}$ century, so we start there. Imports satisfied a significant part of Latin American total textile demand in the 1870s. In a previous paper (Dobado, Gomez and Williamson 2006), we reported that Mexico imported 40 million square meters of cloth in 1879 , compared with 60 million square meters produced domestically. Thus, foreigners supplied $40 \%$ of the domestic market. Yet, these same data imply that domestic producers were able to claim $60 \%$ of the local market, a fairly big number for a country that had been flooded with cheap, factory-made European textiles for almost a century. Indeed, compare Mexican experience with 
that of other parts of the periphery: The share of the domestic market supplied by India's textiles fell from $95 \%$ in 1833 to $35-42 \%$ in $1887,{ }^{4}$ the latter much lower than Mexico's $60 \%$ in 1879 . The de-industrialization forces were even more powerful in the Ottoman Empire where local industry's market share of domestic demand fell from $97 \%$ in the early 1820 s to only $11-38 \%$ in the early 1870 s. ${ }^{5}$ Thus, despite the importance of foreign imports, the Mexican textile industry was doing fairly well by the $1870 \mathrm{~s},{ }^{6}$ at least compared with the rest of the periphery. While we do not have the data to prove it, we doubt that the rest of Latin America was doing as well as Mexico was by the 1870 s, but it appears that some parts of Latin America may have started at a higher base in 1870 s than was true of the rest of the poor periphery.

Table 1 offers more evidence of the prior de-industrialization experience, where Paul Bairoch's (1991) estimates of Brazilian and Mexican industrialization levels are compared with those of Europe and Asia. Between 1800 and 1880, de-industrialization took place throughout what we now call the Third World. While Bairoch's estimates imply that de-industrialization continued up to 1913 in Asia, Brazil and Mexico showed strong signs of recovery, or what we are calling here re-industrialization. Table 2 offers 1910 industrial production per capita figures for cotton yarn, steel, pig iron and cement, again from Bairoch (1991). While these figures confirm that Latin America was well behind the industrial leaders in the European core and their offshoots, only Japan out-performed Mexico in the poor periphery. The number two contender, Brazil, exceeded Mexico in one category, cotton yarn production, but was behind in the other three. Still, Brazil exceeded China, Egypt, the Ottoman Empire and India. There were also some modest signs of industrial success in Chile, at least in per capita cement production. According to Bairoch's estimates, the rest of Latin America was far behind, still conforming to the new international economic order by specializing in primary products. Table 3 offers another index of

\footnotetext{
${ }^{4}$ The 1833 estimate and the smaller of the two 1887 estimates are from Roy (2000: 126). The larger 1887 estimate comes from Tomlinson (1993: Table 3.3, 107).

${ }^{5}$ Pamuk (1986: Table 1, 211). The wide range for $1870-1872$ is due to assumptions about the treatment of yarn imports. Both are far lower than Mexico, however.

${ }^{6}$ For more confirmation, see Keremitsis (1987: 703).
} 
industrial performance at the end of the period, net exports (+) or imports (-) of cotton textile manufactures per capita in 1910, an index that includes yarn, thread and cloth of all sorts. Mexico had a cotton textile net import balance of close to zero, US\$0.24 per capita, compared with the net export position of the United Kingdom of US\$11.25 per capita. No Latin American country did better than Mexico, the closest competitor being Brazil (net imports of US\$1.04 per capita), and most did far worse. Indeed, Argentina (net imports of US\$5.47) joined Australia (US\$8.70) in recording the highest dependence on imported cotton textile manufactures in the periphery.

As one additional piece of evidence to identify how the Latin American industrial leaders were doing early in the $20^{\text {th }}$ century, the first panel of Table 4 reports estimates of the share of the home textile goods market supplied by domestic industry. Two facts leap out of the table. First, by the early $20^{\text {th }}$ century, Brazil's domestic textile industry had carved out an impressive share of its local market, 65.3 percent, but that share was considerably smaller than that of Mexico, 77.9 percent. By this gauge alone, Mexico was more successful industrially than was Brazil. Argentina, on the other hand, could report very little industrial success by 1913 , local industry claiming only 15.5 to 17.5 percent of the home textile market. So much for light industry. The second panel of Table 4 reports smaller market shares for heavy industrial product groups. Although they are harder to document, what data we do have reports significant domestic shares on the rise for Mexico: its domestic producers' share of the local iron and steel market rose from 6 to 28 percent between 1903 and 1911, while that for coke rose from 17 to 47 percent. The 1913 figure for metals and machinery in Argentina was only 12 percent. Second, Mexico increased significantly its share of the home textile market between early Porfiriato and the Revolution, from 60 to 77.9 percent between 1879 and 1906-1908, an increase of almost 20 percentage points. Table 5 reports the share of the labor force employed in manufacturing between 1895 and 1910 . The figures for Argentina and Chile are surprisingly high, 19-25 percent, given that the rapidly industrializing United States had 'only' reached 19-20 percent between 1870 and 1890. Great Britain, however, had reached 29 percent by 1801 and 33 percent in 1910. Oddly enough, the 
figures for Mexico (11-12 percent) seem very low, perhaps because the source excluded or understated small scale manufacturing without mechanical power.

These facts offer strong support for the view that the Latin American industrial leaders did indeed experience a lift off before 1913, and certainly long before the 1930s and its early ISI policies. There must have been rapid industrialization in Brazil and Mexico during the four decades after 1870. The question, however, is when the lift off happened.

Stephen Haber (2002) has argued that the true liftoff of Mexican industry came towards the last third of the 19th century. Haber dates the beginning of the liftoff in the late 1880s. Almost half a century after Mexico's initial mechanization efforts, the 1888 industry was, according to Haber, still small and unproductive (although bigger and more productive than almost anywhere else in the poor periphery). But in the decade that followed, "the industry more than doubled in size. By 1911, the industry had grown an additional 50 percent. Estimates of total factor productivity (TFP) growth ... indicate increases of between 1.5 percent (lower bound) and 3.3 percent (upper bound) per year. Labor productivity grew even faster ... between 3.0 and 4.7 percent per year" (Haber 2002: 7-8). Such growth rates meant that Mexican textile producers had displaced most imported cloth by 1914 (Haber 2002: 11). Tables 3 and 4 confirmed Haber's inference: the first showed that Mexican net imports of cotton manufactures per capita were almost zero in 1910, and the second showed that local producers claimed more than threequarters of the domestic market for all textiles in 1906-08. The only foreign textiles still being imported were high quality, fine-weave cloth. Table 4 suggests a modification to Haber's dating of the Mexican liftoff; the trade data suggest it got a somewhat earlier start than 1888 .

In an effort to better identify Latin American industrial leaders and the timing of their industrialization experience in the decades before World War I, Table 6, Table 7 and Figures 1-3 report evidence based on exports to Latin America from the United States and the United Kingdom. These were the main suppliers of industrial intermediates, energy sources and capital goods used in Latin American industry, so we assume that manufacturing machinery, iron and 
steel, and coal imports (in constant US dollars) are good proxies for relative industrial growth. Tables 6-7 and Figures 1-3 allow us to compare industrialization progress 1870-1914 between Latin American countries. Others have used similar data before (Suzigan 1986; Kuntz 2007), but not comparatively as we do here. Recently Xavier Tafunell, Albert Carreras and César Yañez have used data documenting capital goods exports to Latin America to assess gross capital formation levels in twenty Latin American countries between 1890 and 1930 (Yañez, Rubio and Carreras 2006; Tafunell 2007a; Tafunell 2007b; Tafunell and Carreras 2008). Their work has shown that these data are reliable, and that most machinery exports to Latin America came from just three nations: the United States, the United Kingdom and Germany (for eight Latin American countries in $1913,86.5 \%$ of total machinery exports to the region).

Here we consider only the machinery and iron and steel products that were used by manufacturing, that is, following Wilson Suzigan, we exclude all agricultural and railroad related machinery. We aggregate imports from the United States and United Kingdom only, which accounted for $63.3 \%$ of machinery imports by eight Latin American countries in 1913 . $^{7}$ Since we wish to compare trends and not the levels of machinery imports across Latin America, we do not think our exclusion of German and other country machinery exports to Latin America is a problem.

Figure 1 plots the import time series for the combination of manufacturing machinery (hereafter machinery), iron and steel (hereafter iron) and coal from 1870 to $1914(1900=100)$. According to this proxy, all four of these Latin American countries - Argentina, Brazil, Chile, and Mexico - exhibited impressive growth over the four decades. True, three of them underwent high volatility: Argentina, Brazil and Chile all recorded big booms in the late 1880s-early 1890s

\footnotetext{
${ }^{7}$ Tafunell (2007). According to Carreras and Tafunell (2008), the UK+US machinery import shares in total Latin American machinery imports were the following: Argentina 60.6\%, Brazil 56.6\% Chile 56.3\%, and Mexico 85.2\%. However, the comparison of our Brazilian data with Suzingan's (which includes UK, US and Germany) indicates that 1913 was the year when our data (which includes UK and US) was the lowest relative to Suzigan's (57.3\%). As an average over 1870-1914, our series was 99.3\% of Suzigan's and both series have exactly the same trend.
} 
and again in the run up to WWI, as well as a big bust in the 1890s. Mexico did not undergo this volatility before 1900, but, of course, it did undergo a secular slow down up to and during the Revolution. Figure 2 breaks out machinery imports separately, but the series shows pretty much the same trends. Figure 3 plots the combination of machinery, iron and coal as a share of Gross Domestic Product (in 1990 US dollars). The volatility is still there for Argentina, Brazil and Chile, but the growth seen in Figure 1 has disappeared from the three: between 1870-1874 and 1900-1904, the share of those combined imports in GDP fell for both Argentina and Chile, and it rose hardly at all for Brazil. In contrast, before the run up to the Revolution, Mexico's share increased seven times!

Now consider Tables 6 and 7, where we report the growth rates of both proxies (in US dollars). Table 6 documents growth rates of the combined import package: the volatility of Argentina, Brazil and Chile is revealed once more, and so is Mexico's dominant industrialization (at least according to this proxy). Between 1871 and 1901, Mexico grew almost twice as fast as the average (10.89 versus 5.68 percent per annum), and it grew faster even when the run up to and including the Revolution is included (1871-1911, 7.44 versus 5.65 percent per annum). In addition, the table shows that the lift off was during the first two decades, not later as Haber suggested. That is, the average growth rate of the four was 6.97 percent per annum before 1891 and 4.37 after. Some of this slow down can, of course, be attributed to Mexico's special political problems, but the same slow down is apparent for Argentina and Brazil. The growth of manufacturing machinery itself reported in Table 7 repeats the findings of Table 6: prior to 1891, Mexican growth rates exceed the average, 10.95 versus 7.30 percent per annum, and the growth rates before 1891 (10.42 percent) exceed those afterwards (3.75 percent).

To summarize, we have documented the following: industrialization of the economic leaders in Latin America was very impressive between 1870 and 1913, especially compared with the rest of the poor periphery; Mexico underwent the most impressive industrialization performance; and the lift off occurred well before 1890, not after. 


\section{Some Leading Non-Competing Explanations for the Latin American Industrial Liftoff}

What explains the timing and the pace of the Latin American industrial lift off? It seems to us that there are five likely candidates, candidates that we hope future research will be able to assess more precisely than we are able to do here.

First, it has been shown that Latin America was far more protectionist than anywhere else in the late $19^{\text {th }}$ century (Coatsworth and Williamson 2004). Figure 4 shows that Latin America had the highest tariffs in the world from the late 1880s onwards (Argentina, Brazil, Chile, Columbia, Peru and Mexico among the most protectionist), ${ }^{8}$ and that before the late 1880 s only the United States had higher average tariff rates. Furthermore, these average tariff rates were on the rise between 1865 and 1890, and they were maintained at that high level until just prior to World War I. Perhaps more to the point, Mexico adopted far more coherent and consistent proindustrial tariff policies under the Porfiriato regime. Latin American policy-makers in the late $19^{\text {th }}$ century Latin America were certainly aware of infant industry arguments (Bulmer-Thomas 1994: p.140), but tariffs were not used specifically and consciously to foster industry in Mexico until the early 1890s. Edward Beatty (2001) and Graciela Márquez (2002) have argued persuasively that the 1880 s and 1890 s saw the introduction of a modern pro-industrial policy in Mexico, including a rational structure of protection. This policy was followed with a lag elsewhere in Latin America, Brazil and Chile a little later in the 1890s, and Colombia in the early 1900s (Coatsworth and Williamson 2004a; 2004b). Haber agrees with Márquez and Beatty: "In 1891 Mexico was using tariffs to protect the cotton textile industry" which perhaps would have otherwise been uncompetitive. "This meant high tariffs on competing goods and low tariffs on inputs. The tariff on imported cloth tended to be twice that of the tariff on imported raw cotton. The result was an effective rate of protection that varied from 39 to 78 percent" (Haber 2002:

\footnotetext{
${ }^{8}$ The tariff rates would, of course, be even higher if we looked only at manufacturers.
} 
16). ${ }^{9}$ This explanation is especially appealing since we want to account for the fast Mexican industrial liftoff compared with the rest of the periphery. Most of Asia and the Middle East did not have the autonomy to pursue pro-industrial policies, and we also know that pro-industrial Mexican policy led the rest of the autonomous Latin American republics by a decade or two.

We do not deny that the more rational protectionist policy increased its support for local industry. However, this paper will explore the additional impact of four other influences. The first is world prices and the net barter terms of trade. We will show below that there was a big secular change in world relative prices facing the Mexican economy after the 1870 s, a change that no longer penalized local manufacturing, and textiles in particular. Elsewhere, we have shown that a good part of the exceptionally modest Mexican de-industrialization experience in the century before 1870 was due to an exceptionally modest terms of trade shock compared to the rest of Latin America, Asia and the Middle East (Williamson 2006a, 2006b; Dobado, Gómez and Williamson 2006). We think the same was true of the half century after 1870, but in the opposite direction: as we show below, Latin America's terms of trade fell earlier and faster than anywhere else in the periphery, especially for Mexico. Second, there was also an acceleration in total factor productivity growth in one key export activity in Latin America, mining. This served to contribute to the fall in the net barter terms of trade, but, given a price elastic demand facing silver, copper and other metals, it also served to raise the income terms of trade. It appears that these productivity events were unusual for the poor periphery at that time, including much of Latin America itself. Third, there is some evidence supporting the view that, compared with the rest of the periphery, Latin American industry may have been kept more competitive since it faced weaker upward pressure on the nominal wage, forces induced by weaker upward pressure on food prices. The latter can be explained by policy towards food imports and domestic market integration by the railroads. Finally, there is the impact of the depreciation of local currencies to

\footnotetext{
${ }^{9}$ By 1960, Mexico had much lower tariffs on capital goods and industrial raw materials than did Argentina or Brazil (Taylor 1998; Haber 2006: Table 13.8, p. 574).
} 
consider. As we shall see, the biggest real exchange rate depreciation between 1870 and 1913

took place in Brazil and Mexico, especially the latter, forces which must have contributed to their impressive industrialization performance.

\section{No More Dutch Disease? The Big Change in Latin American Net Barter Terms of Trade Trends}

Did Latin America face a big secular change in world relative price trends, a change that no longer penalized local manufacturing, and textiles in particular? If so, was the secular change bigger than elsewhere in the poor periphery, especially among the Latin American industrial leaders?

Figure 5 suggests the answer is most definitely yes. There we see that after the net barter terms of trade for Latin America reached a secular peak in the mid-late 1870s, it leveled off up to the early-mid 1890s, after which it also fell far more dramatically up to the early 1900s than elsewhere in the periphery. It never recovered even a third of the previous peaks by 1913. Between 1870-74 and 1909-13, the terms of trade in Latin America fell by 10\% (Table 8), this after rising by $174 \%$ over the seven decades between 1800-04 and 1870-74 (Williamson 2008)! In contrast, the rest of the periphery underwent no net fall over the four decades: the Middle East and Southeast Asia underwent a continuous terms of trade improvement from the mid-1870s onwards, while South Asia and East Asia underwent no change either way. Figure 6 shows which parts of Latin America underwent the biggest changes in terms of trade trend. In contrast with Argentina and Chile, Mexico underwent a big fall in its terms of trade after the early-mid 1890s: the Mexican terms of trade was cut in half between 1890 and $1902,{ }^{10}$ twice as big as the rest of Latin America (see also Salvucci 2006: Table 7.6, p. 283). Furthermore, while the primary product boom in the decade or so before 1913 is reflected in a rise in terms of trade everywhere in the poor periphery, the rise was very modest in Mexico, and that rise did not come close to

\footnotetext{
${ }^{10}$ The real exchange rate also depreciated by about 50\% just between 1885 and 1892 (Catão 1998: 74), and it never recovered. We return to this in Section 7 below.
} 
recovering the secular peak in the late 1870 s and early 1880 s. Indeed, the Mexican terms of trade fell by $37.2 \%$ between $1870-74$ and $1910-13$ (Table 8 ), while it rose by $11 \%$ in the rest of Latin America. ${ }^{11}$ While Mexico was exceptional compared with the Latin American average, there are other deviants also plotted with thick solid lines in Figure 6 and reported in Table 8, namely, Cuba (-21.7\%) and Peru (-27.5\%). Brazil and Venezuela underwent hardly any change at all in their terms of trade over the four decades, but even this stability represented a marked change in world economic conditions after 70 years of rising terms of trade and thus falling relative prices of manufactures. Brazil and Venezuela also underwent a huge fall in their terms of trade between the early 1890s and World War I. So did Columbia, but in that case the run up to the 1890s offset the post-1890s collapse.

In summary, a fall (or no rise) in the net barter terms of trade implied a rise (or no fall) in the relative price of imported manufactures, an event which favored (or no longer penalized) domestic industry. If a rising terms of trade caused de-industrialization in the six or seven decades before the 1870s (Dobado, Gómez and Williamson 2006; Williamson 2008), it follows that a falling or stable terms of trade after 1870 should have helped cause a good share of Mexican, Brazilian and even Venezuelan industrialization experience up to 1913.

\section{Productivity Growth, the Income Terms of Trade, and Export-Led Growth in Latin America}

So far, we have assumed that the Latin American republics had no influence over their export or import prices, and thus that their terms of trade was determined exogenously in world markets. While this was certainly true of those countries in Table 8 whose commodity exports were only a small share of world exports of that commodity - like Argentina (maize, wheat), Columbia (coffee, gold), Cuba (sugar, tobacco), Peru (copper), Uruguay (wool, meat), and Venezuela (coffee, cacao), it certainly was not true of the others in Table 8 - Chile (nitrates,

\footnotetext{
${ }^{11}$ This is based on a 1870 population weighted average of Argentina, Brazil, Chile, Colombia, Cuba, Peru and Uruguay, all reported in Table 5.
} 
copper), Mexico (silver), and Brazil (coffee, rubber). Indeed, Edward Beatty (2000) has argued persuasively that Mexican mineral supplies to the world market, especially silver, did indeed help precipitate the big decline in its net barter terms of trade: by flooding the market with silver, Mexico lowered the world price of silver and worsened its terms of trade. Beatty also argues that it was rapid productivity advance in Mexican mining that produced that result, but since the demand for minerals was price elastic, total export values and foreign exchange earnings boomed, creating export-led growth.

Figure 7 describes the two hypotheses. In case 7B, the country takes its export prices as exogenous: export prices fall in world markets (from P to P'), but domestic supply expands sufficiently fast ( $\mathrm{S}$ to $\mathrm{S}$ ') to offset the price decline, augmenting total export revenue. One can imagine an even greater domestic supply shift (to S") which would have produced more exports and more foreign exchange earnings. Clearly, whatever economic success one observed in this case would be attributed unambiguously to the domestic export supply growth, rather than to changing conditions in world markets. In any case, the fall in its net barter terms of trade $\left(\mathrm{P}_{\mathrm{X}} / \mathrm{P}_{\mathrm{M}}\right)$ could not have been a powerful industrialization stimulus in this case since the improved relative price of industrial output must have been at least partially offset by the improved productivity in the commodity export sector that pushed S to S' or S', ${ }^{12}$ This case seems to apply to Cuba, Peru and Venezuela, countries in Table 8 which experienced a decline in their net barter terms of trade and only a very modest improvement in their income terms of trade. Now consider the case in 7B where export prices rise (from P to P"), a case which appears to apply to Argentina and Colombia, both of which underwent a big increase in their net barter and their income terms of trade. No stimulus to industrialization in this case either, but rather de-industrial penalties. Although we do not have income terms of trade estimates for Uruguay, we suspect the same would apply to it as well.

\footnotetext{
${ }^{12}$ Unless, of course, productivity growth was faster in manufacturing where prices were fixed by world market conditions.
} 
Now consider Beatty's hypothesis in Case 7A. Here, the same export supply expansion (S to S') lowers the country's export price since it's a big player in world markets. But given a price elastic demand, and given an additional outward shift in demand (D to D'), export revenues and foreign exchange earnings expand: the bigger the outward supply shift (and productivity advance in the export sector), the bigger the fall in the net barter terms of trade and the rise in the income terms of trade. Mexico appears to be the exception which proves Beatty's rule: a very big decline in the net barter terms of trade (after a long secular boom) was consistent with a very big increase in the income terms of trade. If Beatty's evidence of rapid productivity growth in Mexican mining holds up, we have an explanation for Mexico's income terms of trade rising and its net barter terms of trade falling. While Table 9 confirms this prediction (a result Beatty found with other data), Beatty's supply side argument cannot apply to mineral-producing Chile, since its net barter terms of trade did not fall, but rather rose. Table 9 also suggests that the hypothesis gets ambiguous support at best for Brazil: in this case, the net barter terms of trade was stable after the long and spectacular pre-1870 boom while the income terms of trade underwent only a modest increase.

\section{Keeping the Lid on Wages? The Own Wage and Industrial Competitiveness in the Latin American}

Table 5 documents that the share of the 1895 labor force in manufacturing ranged from a quarter in Argentina and Chile to an eighth in Mexico. These employment shares imply that real wages - nominal wages divided by the cost of living (w/Pc) -- were determined by labor productivity elsewhere in the economy - mining, construction, agriculture and services - not in manufacturing itself. Slow-growing labor productivity in the rest of the economy would have given Latin American manufacturing the advantage of modest upward pressure on per unit wage costs, making it more competitive with North America and western Europe, where the upwards pressures were much stronger. It was, of course, the own-wage that mattered to employers in manufacturing, the nominal wage divided by the price of manufactures $(\mathrm{w} / \mathrm{Pm})$. If the price of 
foodstuffs $(\mathrm{Pa})$ was the central determinant of the cost of living in Latin America, and if $\mathrm{Pa} / \mathrm{Pm}$ was falling, we would have another reason to expect local manufactures in Latin America to have undergone increasing wage competitiveness compared with foreign firms. Is there any reason to think that $\mathrm{Pa} / \mathrm{Pm}$ should have fallen? Yes, and for two reasons: first, to the extent that the post1870s grain invasion flooded Latin American markets in grain importing regions; and second, to the extent that railroads brought cheaper grain in to urban interior markets where manufacturing was located (Dobado and Marrero 2005). The issue is how much?

Table 10 reports $\mathrm{Pa} / \mathrm{Pm}$ for three countries which offer the necessary times series data -Brazil, Mexico and Uruguay. Mexico recorded the biggest $\mathrm{Pa} / \mathrm{Pm}$ decline from 1874-1878 to 1913, 34 percent; Brazil the second, 21 percent; and Uruguay the third, 11 percent. Thus, the grain-invasion-cum-railroads prediction is confirmed, and, furthermore, the two fastest industrializing countries recorded the biggest fall in $\mathrm{Pa} / \mathrm{Pm}$.

But did cheaper grains necessarily mean lower nominal wages and thus greater wage competitiveness of local manufacturing? Table 11 reports the own-wage facing manufacturing firms (w/Pm) for four countries which offer the necessary time series data -- Brazil, Chile, Mexico and Uruguay. Based on this evidence, it appears that Brazil and Uruguay had the industrial advantage on this score since the upward pressure on the own-wage in manufacturing was much greater in Chile and Mexico. Indeed, over the period 1870-1913 as a whole, the ownwage in Brazil grew no faster than it did in the United States, the former remaining competitive with the latter on that score at least. By the same criteria, wage competitiveness in Chile deteriorated relative to the United States, as did that of Mexico (but not as much as Chile). Of course, there were other forces determining competitiveness, but if we are looking for explanations for precocious industrialization in Brazil and Mexico, better wage competitiveness was not one of them, although the former did better on this score than did the latter. 


\section{Did Real Currency Depreciation Increase Manufacturing Profitability?}

Depreciation of the domestic currency favors local manufacturing since it makes imported manufactures more expensive in the local market. Currency appreciation does the opposite. When trading partners have different rates of inflation, the nominal exchange rate must be adjusted to take account of the differential inflation rates, yielding a real exchange rate. The real exchange rate (RER) is yet another force which could have helped account for the timing and pace of industrialization in Latin America before 1913.

Figure 8 plots the RER for four Latin American republics - Argentina, Brazil, Chile, and Mexico. The figure makes it quite clear that manufacturing in Chile must have been greatly disadvantaged by real exchange rate trends, since it underwent significant real currency appreciation. Although its RER trends are not plotted in Figure 8, this was even truer of Colombia which underwent a 20 percent real currency appreciation 1881-1899 (Meisel and López 1990), an even more spectacular appreciation during the inflation 1899-1905, and then stability 1905-1913 (GRECO 2002). The appreciation of the RER must have slowed down the first symptoms of modern industrial development in Colombia during the late $19^{\text {th }}$ century, delaying that process until the beginning of the $20^{\text {th }}$ century (Ocampo 1984, 192). Argentina underwent no secular change in its real exchange rate between 1884 and 1913, so it could not have offered any stimulus to import-competing manufacturing there. However, the real exchange rate did undergo secular depreciation in Brazil and Mexico, and the magnitudes appear to have been big: Mexico underwent a real currency depreciation of 82 percent between the mid 1870s and 1913 and Brazil underwent a real currency depreciation of 36 percent between the early 1870 s and 1913 .

In short, some part of the industrial lift off in Brazil and Mexico can indeed be explained by a real exchange rate depreciation up to 1913. This was not true of Argentina, Chile or Colombia. 


\section{A Future Research Agenda: Decomposing the Sources of the Industrial Lift Off}

This paper does not offer any explicit empirical decomposition of the sources of the industrial liftoff in Latin America between 1870 and World War I, although we certainly hope that future research will do so. At this point, we do not believe that the evidence is sufficient for that demanding task. Thus, we have been content to lay out the contending explanations, to offer what we hope is some plausible support for them, and to set out an agenda. Still, when future research offers an explicit empirical decomposition of the industrial lift off, this paper will have shown how those decompositions are likely to have differed across countries, and which are likely to have been the major actors.

Our prior is that changing fundamentals will end up playing a much more modest role in contributing to the industrial lift off than the current neo-institutional literature supposes. We stress the word changing, since it had to have been changing fundamentals raising productivity in manufacturing, or changing external terms of trade or domestic wage competitiveness improving profitability in manufacturing, or changing tariff and real exchange rates improving profitability in manufacturing that accounted for the lift off, not levels of any of the three.

Changing external terms of trade must have played a big role, as the immense pre-1870 boom in the external terms of trade - a pre-1870 fall in the relative price of imported manufactures, switched to a post-1870 bust in the external terms of trade - a post-1870 rise in the relative price of imported manufactures. What had been a sickly Dutch disease before 1870 became a healthy Dutch revival after 1870. Furthermore, Mexico underwent the biggest reversal in its secular terms of trade trends, followed by Brazil and Venezuela. Thus, industrialization was favored in these three republics compared to the rest of Latin America. These forces were strong and it is time for the literature to pay more attention to them.

Changing tariff and real exchange rate policy also must have played a big role. Tariff rates on manufactures rose in Latin America over these four decades, and the effective rate of protection rose even more as the tariff structure was rationalized. Since Mexico led the way, it 
had the first strike advantage of effective pro-industrial policy, and this long before the early-ISI protectionist policies of the 1930s. In addition, the real exchange rate depreciated for both Brazil and Mexico, offering more benefits to import-competing industry. Since the other major Latin American republics did not undergo the same real currency depreciation, the two leaders enjoyed a first strike pro-industrial advantage - this long before the well-known real currency depreciations of the 1930 s.

We doubt that improved wage competitiveness played a role, since the effects, though positive, were too small to matter much.

It is important to get more precise answers to the sources-of-the-lift-off question. We have been able to document impressive industrialization rates among the Latin America leaders Brazil and Mexico - between 1870 and 1913. We will understand much better the impact of Latin American ISI policies between the 1930s and 1970s, let alone the free trade policies that followed in the late $20^{\text {th }}$ century, when they are linked more closely to the industrialization lift off before 1913, and the policies and prices that produced it. 


\section{References}

P. Bairoch (1991), "How and Not Why; Economic Inequalities Between 1800 and 1913: Some Background Figures," in J. Batou (ed.), Between Development and Underdevelopment (Geneva: Librairie).

E. Beatty (2000), "The Impact of Foreign Trade on the Mexican Economy: Terms of Trade and the Rise of Industry 1880-1923,” Journal of Latin American Studies 32: 399-433.

E. Beatty (2001), Institutions and Investment. The Political Basis of Industrialization in Mexico Before 1911 (Stanford, Cal.: Stanford University Press).

C. Blattman, J. Hwang and J. G. Williamson (2006), "The Impact of the Terms of Trade on Economic Development in the Periphery, 1870-1939: Volatility and Secular Change," Journal of Development Economics (forthcoming).

J. Braun, M. Braun, I. Briones and J. Díaz, Economía Chilena 1810-1995. Estadísticas Históricas Working Paper No. 187. Pontificia Universidad Católica de Chile, January 2000.

V. Bulmer-Thomas (1994), The Economic History of Latin America Since Independence (Cambridge: Cambridge University Press).

L. Catão (1998), "Mexico and export-led growth: the Porfirian period revisited," Cambridge Journal of Economics 22, 1(January): 59-78.

W. A. G. Clark (1909), Cotton Goods in Latin America, Part I: Cuba, Mexico, and Central America. Special Agent Series No. 31 (Washington, D.C.: Department of Commerce and Labor, Bureau of Manufactures, U.S. Government Printing Office).

W. A. G. Clark (1910), Cotton Goods in Latin America, Part II: Brazil, Colombia, and Venezuela. Special Agent Series No. 36 (Washington, D.C.: Department of Commerce and Labor, Bureau of Manufactures, U.S. Government Printing Office).

J. H. Coatsworth and J. G. Williamson (2004a), "Always Protectionist? Latin American Tariffs from Independence to Great Depression," Journal of Latin American Studies 36, part 2 (May): 205-32.

J. H. Coatsworth and J. G. Williamson (2004b), "The Roots of Latin American Protectionism: Looking Before the Great Depression." In A. Estevadeordal, D. Rodrik, A. Taylor and A. Velasco (eds.), FTAA and Beyond: Prospects for Integration in the Americas (Cambridge, Mass.: Harvard University Press).

Compañía Fundidora de Fierro y Acero de Monterrey (1923), Annual Report to the General Assembly (Mexico City).

R. Cortés Conde (1992), "Export-Led Growth in Latin America: 1870-1930," Journal of Latin American Studies, Supplement, 24: 165-79.

W. Dean (1969), The Industrialization of São Paulo 1880-1945 (Austin: University of Texas Press).

P. Deane and W. A. Cole (1962), British Economic Growth 1688-1959 (Cambridge: Cambridge University Press).

R. Dobado and G. A. Marrero (2005), "Corn Market Integration in Porfirian Mexico," Journal of Economic History 65, 1 (March): 103-28.

R. Dobado, A. Gómez Galvarriato and J. G. Williamson (2006), "Globalization, DeIndustrialization and Mexican Exceptionalism 1750-1879," NBER Working Paper 12316, National Bureau of Economic Research, Cambridge, Mass. (June).

A. Dorfman (1970, Historia de la Industria Argentina (Buenos Aires: Solar).

E. Gallo (1970), "Agrarian Expansion and Industrial Development in Argentina, 1880-1930," in R. Carr (ed.), Latin American Affairs (Oxford: Oxford University Press). 
L. S. Garry (1920), Textile Markets of Argentina, Uruguay and Paraguay. Special Agent Series No. 194 (Washington, D.C.: Department of Commerce and Labor, Bureau of Manufactures, U.S. Government Printing Office).

GRECO (2002) Grupo de Estudios de Crecimiento, El Crecimiento económica colombiano en el siglo XX (Bogotá: Banco de la República y Fondo de Cultura Económica).

E. R. Grilli and M. C. Yang (1988), "Primary Commodity Prices, Manufactured Goods Prices, and the Terms of Trade of Developing Countries: What the Long Run Shows," World Bank Economic Review 2: 1-48.

S. Haber (1989), Industry and Underdevelopment: The Industrialization of Mexico (Stanford: Stanford University Press).

S. Haber (1990), "La economía mexicana, 1830-1940: obstáculos a la industrialización (II)," Revista de Historia Económica 8, 2: 335-62.

S. Haber (2002), "It Wasn't All Prebisch's Fault: The Political Economy of Twentieth Century Industrialization in Latin America." Unpublished, Stanford University.

S. Haber (2006), "The Political Economy of Industrialization," in V. Bulmer-Thomas, J. Coatsworth and R Cortés-Conde (eds.), The Cambridge Economic History of Latin America: Volume II (Cambridge: Cambridge University Press), pp. 537-84.

D. Keremitsis (1987), The Cotton Textile Industry in Porfiriato, Mexico 1870-1910 (New York: Garland Publishing).

S. Kuntz (2007), El comercio exterior en México en la era del capitalismo liberal, 1870-1929 (Mexico: El Colegio de México).

W. A. Lewis (1978a), The Evolution of the International Economic Order (Princeton, N.J.: Princeton University Press).

A. Maddison, Monitoring the World Economy 1820-1992 (OECD: Paris, 1995).

G. Márquez (2002), "The Political Economy of Mexican Protectionism, 1868-1911," PhD thesis, Harvard University (March).

W. Martin (2003), "Developing Countries' Changing Participation in World Trade," World Bank Research Observer 18(20): 187-203.

A. Meisel Roca and A. López Mejia (1990), Papel moneda, tasas de interés y revaluación durante la Regeneración (Bogotá: Banco de la República).

J. A. Ocampo (1984), Colombia y la Economía Mundial 1830-1910 (Bogotá: Siglo XXI editores de Colombia).

Ş. Pamuk (1986), “The Decline and Resistance of Ottoman Cotton Textiles 1820-1913," Explorations in Economic History 23 (April): 205-25.

R. Prebisch (1950), The Economic Development of Latin America and Its Principal Problems (New York: United Nations Economic Commission for Latin America).

T. Roy (2000), The Economic History of India, 1857-1947 (Oxford: Oxford University Press). R. Salvucci (2006), "Export-Led Industrialization," in V. Bulmer-Thomas, J. Coatsworth and R Cortés-Conde (eds.), The Cambridge Economic History of Latin America: Volume II (Cambridge: Cambridge University Press).

W. Suzigan (2000), Industria brasileira: origem e desenvolvimento (Sao Paulo: Hucitec and Unicamp).

Seminario de Historia Moderna de México (1965), Estadísticas Económicas del Porfiriato, Fuerza de Trabajo y Actividad Económica por Sectores (México: El Colegio de México, $1965)$.

H. W. Singer (1950), "The Distribution of Gains between Investing and Borrowing Countries," American Economic Review 40: 473-85.

X. Tafunell (2007), "On the origins of ISI: The Latin American Cement Industry 1900-1930", Journal of Latin American Studies, 39, 2: 299-328. 
X. Tafunell and A. Carreras (2008), “América Latina y el Caribe en 1913 y 1925: un enfoque desde las importaciones de bienes de capital” El Trimestre Económico (forthcoming).

X. Tafunell (2007), "Un factor clave del nexo entre energía y desarrollo durante la primera globalización: la dotación de maquinaria en América Latina, 1890-1930.” Paper presented at the First Congress of Latin American Economic History, Montevideo, December 5-7, 2007.

A. M. Taylor (1998), "On the Costs of Inward-Looking Development: Price Distortions, Growth, and Divergence in Latin America," Journal of Economic History 58 (March): 1-28.

B. R. Tomlinson (1993), The Economy of Modern India, 1860-1970 (Cambridge: Cambridge University Press).

U. S. Department of Commerce (1870-1914), Bureau of Foreign and Domestic Commerce, The Foreign Commerce and Navigation of the United States (Washington, D.C.: USGPO, annual issues).

U. S. Department of Commerce (1975), Historical Statistics of the United States, Colonial Times to 1970: Part I (Washington, D.C.: USGPO).

U. S. Congressional Papers (1912), 82nd Congress, 2nd Session, House Document No. 643, pt. 1 (Washington, D.C.: USGPO).

U. K. Parliamentary Papers (1870-1914), Annual Statement of the Trade of the United Kingdom with Foreign Countries and British Possessions (London: HMSO, annual issues).

J. G. Williamson (2006a), "Globalization, De-Industrialization and Underdevelopment in the Third World Before the Modern Era," Journal of Iberian and Latin American History (Revista de Historia Económica) 241 (Primavera): 9-36.

J. G. Williamson (2006b), Globalization and the Poor Periphery before 1950 (Cambridge, Mass.: MIT Press).

J. G. Williamson (2008), "Globalization and the Great Divergence: Terms of Trade Booms and Volatility in the Poor Periphery 1782-1913," the Hicks Lecture, Oxford University (May 27).

C. Yáñez, M. Rubio and A. Carreras (2006), "Economic modernisation in Latin America and the Caribbean between 1890 and 1925: A view from the energy consumption." Paper presented at the $44^{\text {th }}$ Cliometrics Conference June 2-4 2006, Binghampton (NY). 
Table 1

Per Capita Industrialization Index Relative to 1900 UK and to Europe 1800-1913

$\begin{array}{llllll}1800 & 1830 & 1860 & 1880 & 1900 & 1913\end{array}$

Industrializing Leaders

$\begin{array}{lrrrrrr}\text { Europe } & 8 & 11 & 17 & 23 & 33 & 45 \\ \begin{array}{l}\text { United } \\ \text { Kingdom }\end{array} & 16 & 25 & 64 & 87 & 100 & 115\end{array}$

Future Third World Followers Relative to 1900 United Kingdom

$\begin{array}{lllllll}\text { Brazil } & 5 & 4 & 4 & 4 & 5 & 7 \\ \text { Mexico } & 6 & 4 & 5 & 4 & 5 & 7 \\ \text { China } & 6 & 6 & 4 & 4 & 3 & 3 \\ \text { India } & 6 & 6 & 3 & 2 & 1 & 2\end{array}$

Future Third World Followers Relative to 1900 Europe

$\begin{array}{lrrrrrr}\text { Brazil } & 15 & 12 & 12 & 12 & 15 & 21 \\ \text { Mexico } & 18 & 12 & 15 & 12 & 15 & 21 \\ \text { China } & 18 & 18 & 12 & 12 & 9 & 9 \\ \text { India } & 18 & 18 & 9 & 6 & 3 & 6\end{array}$

Source: Bairoch (1991): Table 1, p. 3. 
Table 2

Industrial Production Per Capita for Four Sectors in 1910

Cotton Yarn Steel Pig Iron Cement

Industrializing Leaders

Europe
United Kingdom
United States
Germany
Japan

4.8

17.6

10.8

6.5

3.8

73
139.4
255.1
204.4
4.4

74

212.1

269.2

198.7

3.8

45.6

63.3

129.9

176.1

10.5

\section{Future Third World Followers}

China
Egypt
Ottoman Empire
India
Argentina
Brazil
Chile
Columbia
Mexico
Peru
Uruguay
Venezuela

0.2

0.1

0.2

0.9

0.1

3.4

0

0.2

2.1

0.6

0

0.2

0.1
0
na

0

0

0.3

0

4.1

0

0

0

$\begin{array}{rr}0.5 & 0.4 \\ 0 & 3 \\ 0 & \mathrm{Na} \\ 0.2 & 1.2\end{array}$

$\begin{array}{ll}0 & 0.4\end{array}$

$\begin{array}{ll}0.2 & 0.1\end{array}$

$0.3 \quad 7.5$

$0 \quad 0.5$

$3 \quad 3.2$

$0 \quad 0$

$\begin{array}{ll}0 & 1.8\end{array}$

0.8

Source: Bairoch (1991): Table 4, p. 10.

Notes: na $=$ not available. 
Table 3. An Index of Industrialization in Latin America around 1910: Net Exports (+) and Net Imports (-) per capita of Cotton Manufactures

$\begin{array}{lrr}\begin{array}{l}\text { Country/Region } \\ \text { Index }\end{array} & \begin{array}{r}\text { Relative } \\ \text { (UK=100) }\end{array} \\ \text { United Kingdom } & 11.25 & 100 \\ \text { English-Speaking Periphery } & & -35 \\ \text { United States } & -3.99 & -3 \\ \text { Canada } & -0.36 & -26 \\ \text { Australia } & -2.94 & -77 \\ & -8.7 & -22 \\ \text { Latin America Periphery } & & -2 \\ \text { Mexico } & -2.43 & -9 \\ \text { Brazil } & -0.24 & -16 \\ \text { Venezuela } & -1.04 & -32 \\ \text { Chile } & -1.78 & -49 \\ \text { Argentina } & -3.62 & -6 \\ & -5.47 & -6\end{array}$

Source: Trade data are from US Department of Commerce (1912), Tables 106 and 107, pp. 214-19. Population data from Maddison (1995).

Note: Regional averages are unweighted. 
Table 4. Comparative Industrialization in Latin America 1879-1913:

\section{Manufacturers Import Penetration}

\section{Percent of Home Textile Market Supplied by Foreign Imports Domestic Industry}

Mexico 1879

Colombia 1870s

Mexico 1906-1908

Brazil 1907

Argentina 1913
40

90

22.1

34.7

$82.5-84.5$
60

10

77.9

65.3

$15.5-17.5$

Textile Sources: Mexico 1879 from Dobado, Gómez and Williamson (2006, Table 4). Mexico 1906-1908 from Clark (1909: 20 and 39). Colombia 1870s from Ocampo (2007: 35). Brazil 1907 from Clark (1910: 6). Argentina 1913 reports two estimates, the lower from Garry (1920: 22 and 31) and the upper from Dorfman (1970: 310).

\section{Percent of Home Manufacturers Market Supplied by \\ Foreign Imports Domestic Industry}

Mexico, iron and steel

1903

1911

Mexico, coke

1904

1911

Argentina, metals

and machinery 1913
94

72

83

53

88
6

28

17

47

12

Other Sources: Mexico 1903-1911 from Compañia (1923). Argentina from Dorfman (1970: 310). 
Table 5. Share of the Labor Force in Manufacturing:

Argentina, Chile, Mexico vs US and GB 1870-1910 (\%)

$\begin{array}{rrrrrr}\text { Year } & \text { Argentina } & \text { Chile } & \text { Mexico } & \text { US } & \text { GB } \\ 1870 & & 24.0 & & 19.9 & 32.5 \\ 1890 & & & & 18.8 & 32.7 \\ 1895 & 24 & 24.6 & 11.7 & & \\ 1900 & & 22.8 & 12.2 & 20.3 & 32.9 \\ 1910 & & 19.0 & 11.5 & 22.2 & 33.3\end{array}$

Sources: Chile from Braun et al. (2000: 218-23); Mexico from Seminario (1965: 48); Argentina from Dorfman (1970: 310); US from Historical Statistics (1972), E167 and E174; and GB from Deane and Cole (1962), p. 143, 1871-1911.

Table 6 Growth Rates per annum in Intermediates and Capital Goods Imports From the US and UK (\$) 1871-1911

$\begin{array}{lccccc}\text { Period } & \text { Argentina } & \text { Brazil } & \text { Chile } & \text { Mexico } & \begin{array}{c}\text { Unweighted } \\ \text { Average }\end{array} \\ 1871-1881 & 3.34 \% & 4.27 \% & -0.55 \% & 15.11 \% & 5.54 \% \\ 1881-1891 & 7.51 & 7.02 & 8.27 & 6.89 & 8.51 \\ 1891-1901 & 5.85 & 3.03 & 2.94 & 10.89 & 3.16 \\ 1901-1911 & 9.98 & 8.07 & 7.43 & -2.29 & 5.80 \\ 1871-1891 & 7.51 & 5.64 & 3.82 & 10.92 & 6.97 \\ 1871-1901 & 5.85 & 3.03 & 2.94 & 10.89 & 5.68 \\ 1871-1911 & 6.86 & 4.26 & 4.05 & 7.44 & 5.65 \\ 1871-1891 & & & & & \\ 1891-1911 & 7.51 & 5.64 & 3.82 & 10.92 & 6.97 \\ & 6.22 & 2.91 & 4.28 & 4.06 & 4.37\end{array}$

Source: The import data are reported exports in 1913 US dollars from the US and the UK in iron and steel, coal and manufacturing machinery. The US data are taken from US Department of Commerce (1870-1913). The UK data are taken from Parliamentary Papers (1870-1914). 
Table 7 Growth Rates per annum in Manufacturing Capital Goods Imports From the US and UK (\$) 1871-1911

\begin{tabular}{lrrrrc} 
Period & Argentina & \multicolumn{1}{c}{ Brazil } & \multicolumn{1}{c}{ Chile } & Mexico & $\begin{array}{c}\text { Unweighted } \\
\text { Average }\end{array}$ \\
$1871-1881$ & $5.82 \%$ & $8.92 \%$ & $-0.04 \%$ & $12.81 \%$ & $6.88 \%$ \\
$1881-1891$ & 20.62 & 10.94 & 13.87 & 11.33 & 14.19 \\
$1891-1901$ & 0.56 & -4.48 & 3.45 & 8.75 & 2.07 \\
$1901-1911$ & 6.88 & 10.23 & 11.32 & -2.82 & 6.40 \\
$1871-1891$ & 12.98 & 9.93 & 6.69 & 12.07 & 10.42 \\
$1871-1901$ & 8.68 & 4.90 & 4.67 & 10.95 & 7.30 \\
$1871-1911$ & 8.23 & 6.21 & 6.29 & 7.33 & 7.02 \\
$1871-1891$ & 12.98 & 9.93 & 6.69 & 12.07 & 10.42 \\
$1891-1911$ & 3.68 & 2.61 & 5.90 & 2.80 & 3.75
\end{tabular}

Source: The import data are reported exports of manufacturing machinery in 1913 US dollars from the US and the UK. See Table 6. 
Table 8. Net Barter Terms of Trade Change in Latin America 1870-74 to $1909-13(1900=100)$

$\begin{array}{lrrr}\text { Country } & \mathbf{1 8 7 0 - 7 4} & \mathbf{1 9 0 9 - 1 3} & \begin{array}{c}\% \\ \text { change }\end{array} \\ \text { Increase } & & & \\ \quad \text { Argentina } & 103.3 & 138.8 & 34.4 \\ \text { Chile } & 83.1 & 148.4 & 78.5 \\ \text { Columbia } & 103.1 & 118.3 & 14.8 \\ \text { Uruguay } & 85.3 & 106.2 & 24.6 \\ & & & \\ \text { Decrease } & & & -37.2 \\ \text { Mexico } & 142.5 & 89.4 & -21.7 \\ \text { Cuba } & 135.3 & 105.9 & -27.5 \\ \text { Peru } & 134.9 & 97.8 & \\ \text { No Change } & & & 0.7 \\ \text { Brazil } & 115.1 & 115.9 & -1.8 \\ \text { Venezuela } & 107.9 & 105.9 & -9.5 \\ & & & \\ \text { Latin America } & 118.1 & 106.9 & \end{array}$

Note: Latin America is a 1870 population weighted average. 
Table 9. Income Terms of Trade (INCTT) Growth 1870-1913 (1900=100)

$\begin{array}{lllllll}\text { NBTT } & 1870 X & (1)(2) / 100= & \begin{array}{l}\text { NBTT } \\ \text { INCTT }\end{array} & 1913 X & (4)(5) / 100= & \text { INCTT } \\ 1870- & & 1909- & & \text { INCTT } & \text { per } \\ 74 & \text { Volume } & 1870 & 13 & \text { Volume } & 1913 & \begin{array}{l}\text { annum } \\ \text { growth }\end{array}\end{array}$

\begin{tabular}{|c|c|c|c|c|c|c|c|}
\hline \multicolumn{8}{|l|}{$\begin{array}{l}\text { NBTT } \\
\text { increase }\end{array}$} \\
\hline Argentina & 103.3 & 19.2 & 19.8 & 138.8 & 170.1 & 236.1 & 5.9 \\
\hline Chile & 83.1 & 38.6 & 32.1 & 148.4 & 163.3 & 242.3 & 4.8 \\
\hline Colombia & 103.1 & 114.0 & 117.5 & 118.3 & 267.0 & 315.9 & 2.3 \\
\hline Uruguay & 85.3 & & & 106.2 & & & \\
\hline \multicolumn{8}{|l|}{$\begin{array}{l}\text { NBTT } \\
\text { decrease }\end{array}$} \\
\hline Mexico & 142.5 & 18.3 & 26.1 & 89.4 & 178.9 & 159.9 & 4.3 \\
\hline Cuba & 135.3 & & & 105.9 & & & \\
\hline Peru & 134.9 & 114.8 & 154.9 & 97.8 & 232.4 & 227.3 & 0.9 \\
\hline \multicolumn{8}{|l|}{$\begin{array}{l}\text { NBTT no } \\
\text { change }\end{array}$} \\
\hline Brazil & 115.1 & 47.2 & 54.3 & 115.9 & 104.4 & 121.0 & 1.9 \\
\hline Venezuela & 107.9 & & & 105.9 & & & \\
\hline Latin America & 118.1 & & & 106.9 & & & \\
\hline
\end{tabular}

\section{NBTT}

Argentina

Chile

Colombia

NBTT

decrease

Mexico

142.5

134.9

114.8

105.9
$154.9 \quad 97.8$

232.

9

\section{NBTT no}

change

Brazil

$115.1 \quad 47.2$

115.9

104.4 price and $\mathrm{Pm}$ the import price. The table uses the first equation. 
Table 10. Prices of Food Relative to Manufactures $(\mathrm{Pa} / \mathrm{Pm})$ in Latin America 1870-1913 (1913=100)

\begin{tabular}{|c|c|c|c|}
\hline Year & Brazil & Mexico & Uruguay \\
\hline 1870 & 99.3 & & 112.0 \\
\hline 1871 & 101.8 & & 110.7 \\
\hline 1872 & 109.8 & & 110.7 \\
\hline 1873 & 109.9 & & 116.2 \\
\hline 1874 & 118.3 & 133.7 & 133.0 \\
\hline 1875 & 114.2 & 135.2 & 116.9 \\
\hline 1876 & 123.0 & 136.3 & 93.8 \\
\hline 1877 & 124.9 & 129.9 & 119.8 \\
\hline 1878 & 123.7 & 135.5 & 92.3 \\
\hline 1879 & 120.0 & 132.7 & 82.2 \\
\hline 1880 & 111.0 & 129.9 & 95.3 \\
\hline 1881 & 112.8 & 125.5 & 89.5 \\
\hline 1882 & 116.1 & 121.2 & 107.8 \\
\hline 1883 & 109.4 & 117.0 & 94.2 \\
\hline 1884 & 111.3 & 112.9 & 96.0 \\
\hline 1885 & 111.2 & 122.5 & 101.7 \\
\hline 1886 & 106.3 & 136.0 & 105.9 \\
\hline 1887 & 116.9 & 142.7 & 104.9 \\
\hline 1888 & 110.3 & 127.2 & 100.2 \\
\hline 1889 & 125.5 & 118.4 & 76.3 \\
\hline 1890 & 114.6 & 117.0 & 86.7 \\
\hline 1891 & 113.4 & 114.4 & 88.4 \\
\hline 1892 & 112.0 & 84.2 & 98.6 \\
\hline 1893 & 131.2 & 86.8 & 103.9 \\
\hline 1894 & 123.0 & 101.4 & 102.8 \\
\hline 1895 & 106.1 & 116.9 & 51.1 \\
\hline 1896 & 105.1 & 107.1 & 98.9 \\
\hline 1897 & 122.1 & 78.4 & 92.9 \\
\hline 1898 & 111.0 & 102.8 & 83.8 \\
\hline 1899 & 90.2 & 126.9 & 87.1 \\
\hline 1900 & 92.4 & 122.7 & 73.9 \\
\hline 1901 & 100.7 & 106.3 & 82.5 \\
\hline 1902 & 94.9 & 96.3 & 83.9 \\
\hline 1903 & 90.4 & 112.8 & 79.7 \\
\hline 1904 & 91.1 & 129.2 & 84.1 \\
\hline 1905 & 94.5 & 97.5 & 77.7 \\
\hline 1906 & 111.8 & 107.2 & 92.7 \\
\hline 1907 & 102.1 & 110.8 & 84.7 \\
\hline 1908 & 104.9 & 100.8 & 87.6 \\
\hline 1909 & 95.4 & 84.3 & 91.8 \\
\hline 1910 & 93.2 & 91.2 & 99.4 \\
\hline 1911 & 103.5 & 89.7 & 107.3 \\
\hline 1912 & 104.4 & 88.5 & 90.4 \\
\hline 1913 & 100.0 & 100.0 & 100.0 \\
\hline \multicolumn{4}{|l|}{$\%$ decline } \\
\hline $1874-8$ to 1913 & $-21 \%$ & $-34 \%$ & $-11 \%$ \\
\hline
\end{tabular}


Table 11. Own-Wage in Latin American Manufacturing 1870-1913 (1913=100)

\begin{tabular}{lccccc} 
Year & Brazil & Chile & Mexico & Uruguay & US \\
\hline $\mathbf{1 8 7 0}$ & 47.3 & 26.9 & & 94.7 & 48.8 \\
$\mathbf{1 8 7 1}$ & 57.7 & 27.8 & & 112.4 & 50.7 \\
$\mathbf{1 8 7 2}$ & 59.9 & 29.1 & & 112.4 & 49.1 \\
$\mathbf{1 8 7 3}$ & 65.5 & 28.3 & & 103.4 & 47.6 \\
$\mathbf{1 8 7 4}$ & 64.7 & 27.5 & & 93.4 & 52.0 \\
$\mathbf{1 8 7 5}$ & 76.4 & 28.7 & & 91.2 & 53.6 \\
$\mathbf{1 8 7 6}$ & 79.4 & 29.1 & & 87.8 & 52.2 \\
$\mathbf{1 8 7 7}$ & 77.5 & 30.7 & 39.1 & 84.1 & 55.6 \\
$\mathbf{1 8 7 8}$ & 72.7 & 31.2 & 40.0 & 81.0 & 58.9 \\
$\mathbf{1 8 7 9}$ & 79.6 & 28.0 & 41.0 & 76.9 & 58.5 \\
$\mathbf{1 8 8 0}$ & 78.6 & 25.3 & 42.2 & 74.4 & 53.9 \\
$\mathbf{1 8 8 1}$ & 76.1 & 26.9 & 43.4 & 78.5 & 61.4 \\
$\mathbf{1 8 8 2}$ & 88.4 & 33.5 & 44.5 & 81.1 & 64.3 \\
$\mathbf{1 8 8 3}$ & 79.7 & 39.0 & 45.7 & 79.4 & 67.5 \\
$\mathbf{1 8 8 4}$ & 90.0 & 41.6 & 46.9 & 83.1 & 72.3 \\
$\mathbf{1 8 8 5}$ & 91.5 & 32.8 & 48.1 & 92.1 & 75.9 \\
$\mathbf{1 8 8 6}$ & 91.2 & 36.5 & 48.8 & 98.3 & 81.0 \\
$\mathbf{1 8 8 7}$ & 102.3 & 34.4 & 47.8 & 100.0 & 84.3 \\
$\mathbf{1 8 8 8}$ & 99.4 & 39.3 & 50.5 & 97.9 & 85.0 \\
$\mathbf{1 8 8 9}$ & 96.5 & 46.8 & 57.2 & 62.6 & 85.0 \\
$\mathbf{1 8 9 0}$ & 90.5 & 46.9 & 56.6 & 89.0 & 82.4 \\
$\mathbf{1 8 9 1}$ & 86.6 & 35.1 & 62.7 & 93.1 & 84.3 \\
$\mathbf{1 8 9 2}$ & 80.6 & 39.4 & 71.4 & 105.5 & 88.9 \\
$\mathbf{1 8 9 3}$ & 82.5 & 32.5 & 76.0 & 115.6 & 82.7 \\
$\mathbf{1 8 9 4}$ & 80.2 & 29.0 & 74.6 & 117.5 & 87.2 \\
$\mathbf{1 8 9 5}$ & 93.3 & 43.5 & 69.7 & 99.0 & 90.8 \\
$\mathbf{1 8 9 6}$ & 78.0 & 46.2 & 69.7 & 94.0 & 94.1 \\
$\mathbf{1 8 9 7}$ & 87.4 & 48.0 & 70.4 & 100.6 & 93.3 \\
$\mathbf{1 8 9 8}$ & 71.2 & 51.8 & 71.7 & 77.1 & 89.8 \\
$\mathbf{1 8 9 9}$ & 73.0 & 48.4 & 72.2 & 78.9 & 90.0 \\
$\mathbf{1 9 0 0}$ & 78.9 & 60.3 & 70.9 & 78.3 & 87.4 \\
$\mathbf{1 9 0 1}$ & 96.9 & 56.5 & 80.0 & 73.0 & 92.3 \\
$\mathbf{1 9 0 2}$ & 102.5 & 60.2 & 84.6 & 94.9 & 88.5 \\
$\mathbf{1 9 0 3}$ & 102.4 & 68.6 & 67.5 & 87.7 & 93.6 \\
$\mathbf{1 9 0 4}$ & 101.8 & 70.1 & 71.5 & 95.9 & 92.8 \\
$\mathbf{1 9 0 5}$ & 125.7 & 75.2 & 81.6 & 93.5 & 92.7 \\
$\mathbf{1 9 0 6}$ & 124.1 & 73.3 & 72.6 & 84.3 & 96.3 \\
$\mathbf{1 9 0 7}$ & 105.4 & 77.7 & 78.3 & 88.4 & 93.6 \\
$\mathbf{1 9 0 8}$ & 110.6 & 82.5 & 74.8 & 92.3 & 89.9 \\
$\mathbf{1 9 0 9}$ & 114.3 & 77.3 & 88.9 & 106.3 & 90.0 \\
$\mathbf{1 9 1 0}$ & 112.1 & 76.8 & 79.0 & 106.4 & 92.0 \\
$\mathbf{1 9 1 1}$ & 112.3 & 77.0 & 81.3 & 106.8 & 100.3 \\
$\mathbf{1 9 1 2}$ & 101.3 & 89.9 & 108.4 & 105.7 & 96.0 \\
$\mathbf{1 9 1 3}$ & 100.0 & 100.0 & 100.0 & 100.0 & 100.0 \\
& & & & &
\end{tabular}


Figure 1. Index of Coal, I ron \& Steel, and Machinery I mports in Constant US dollars $(1900=100)$

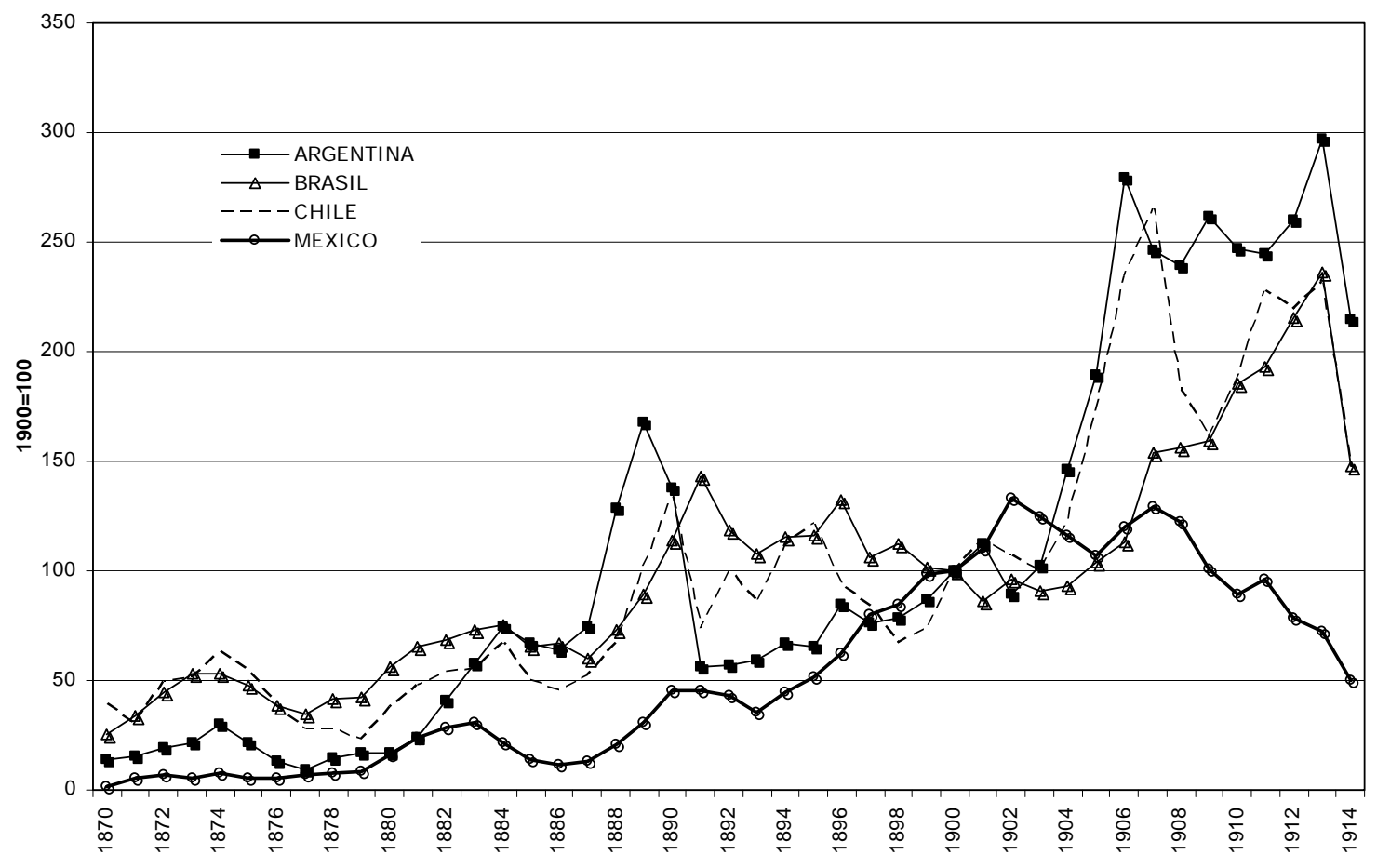


Figure 2. I ndex of Machinery I mports in Constant Dollars $(1900=100)$

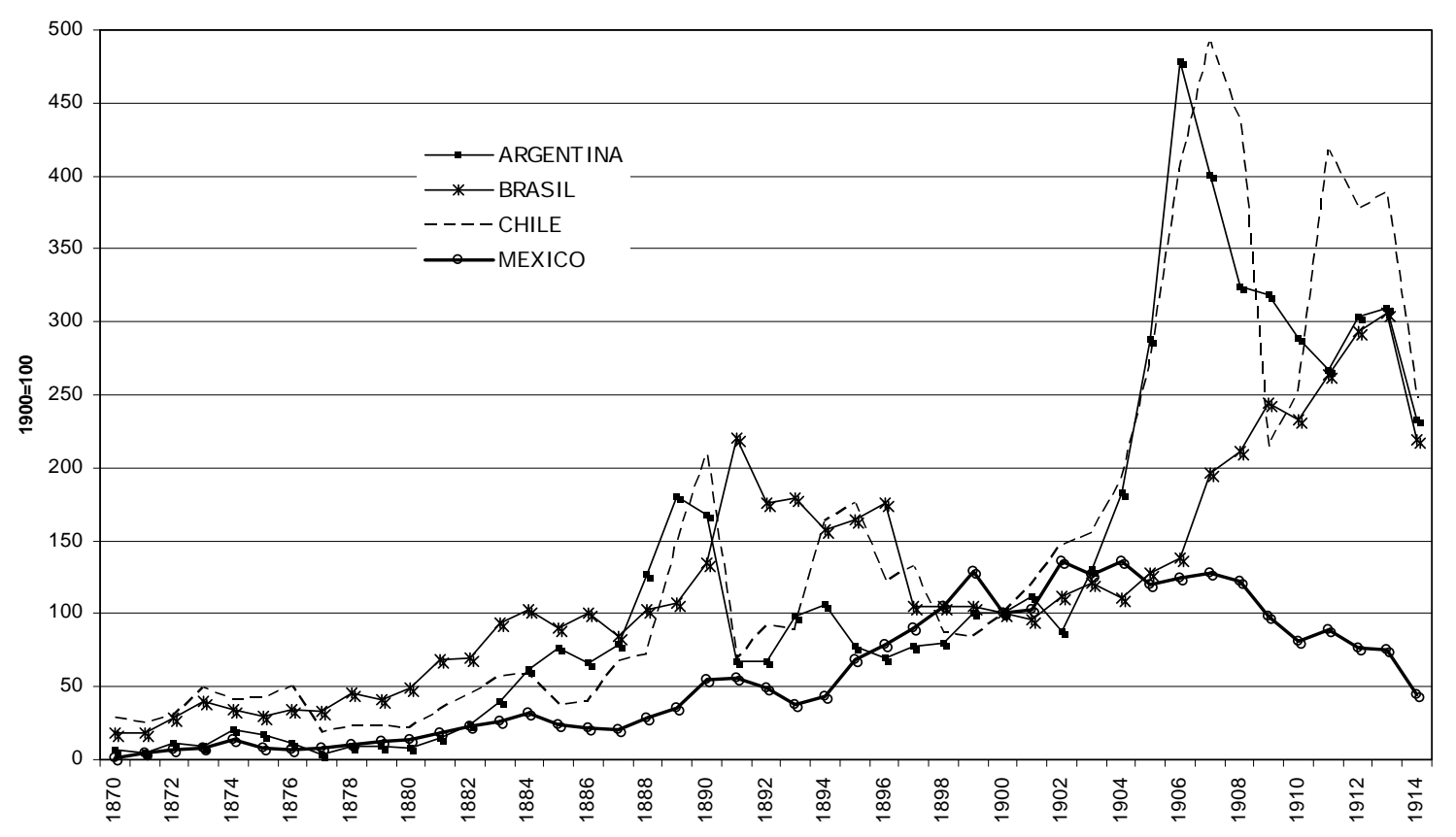


Figure 3. Machinery, I ron and Coal I mports from the USA and UK Relative to GDP

(in G-K 1990 US\$)
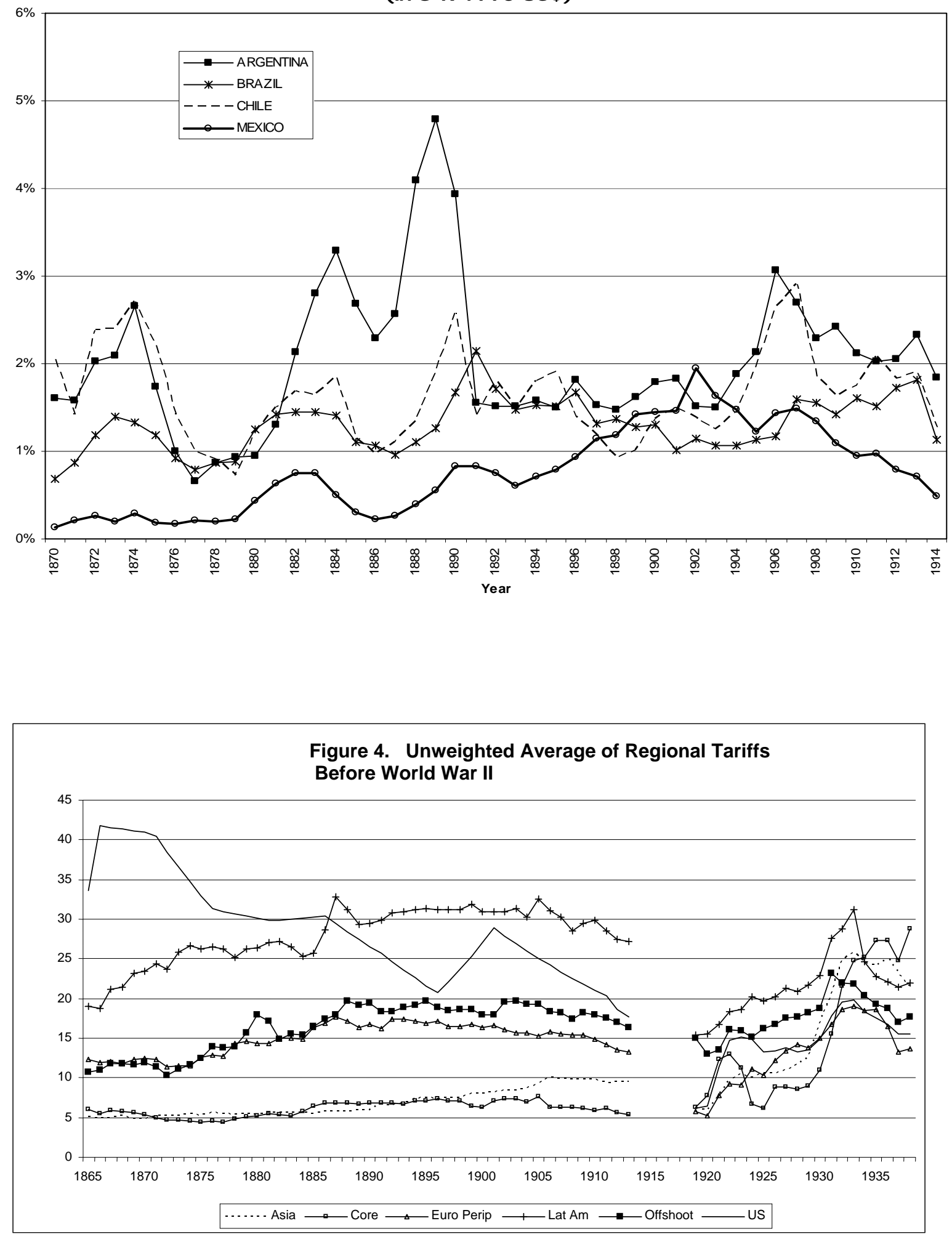
Figure 5. The Poor Periphery: Net Barter Terms of Trade 1796-1913
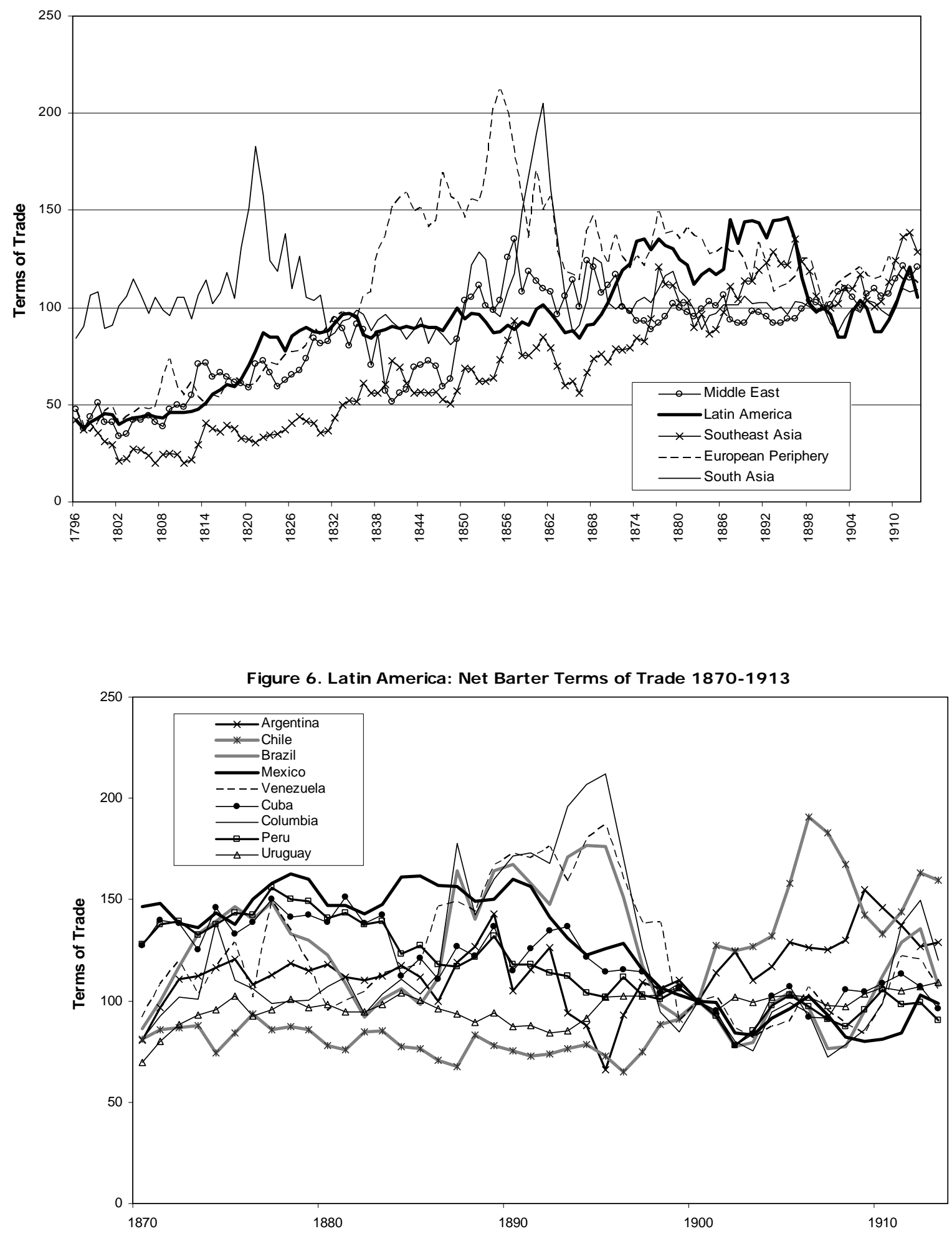
Figure 7 Alternative Views of the Terms of Trade in Latin America

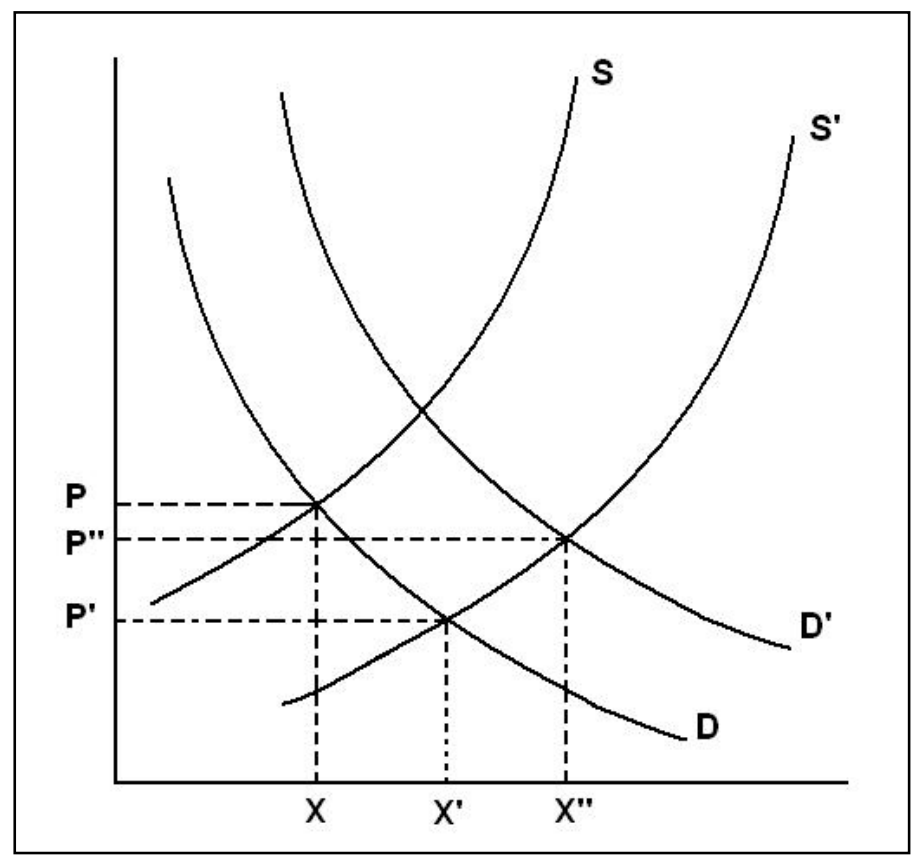

Figure 7A The Endogenous Export Price Hypothesis

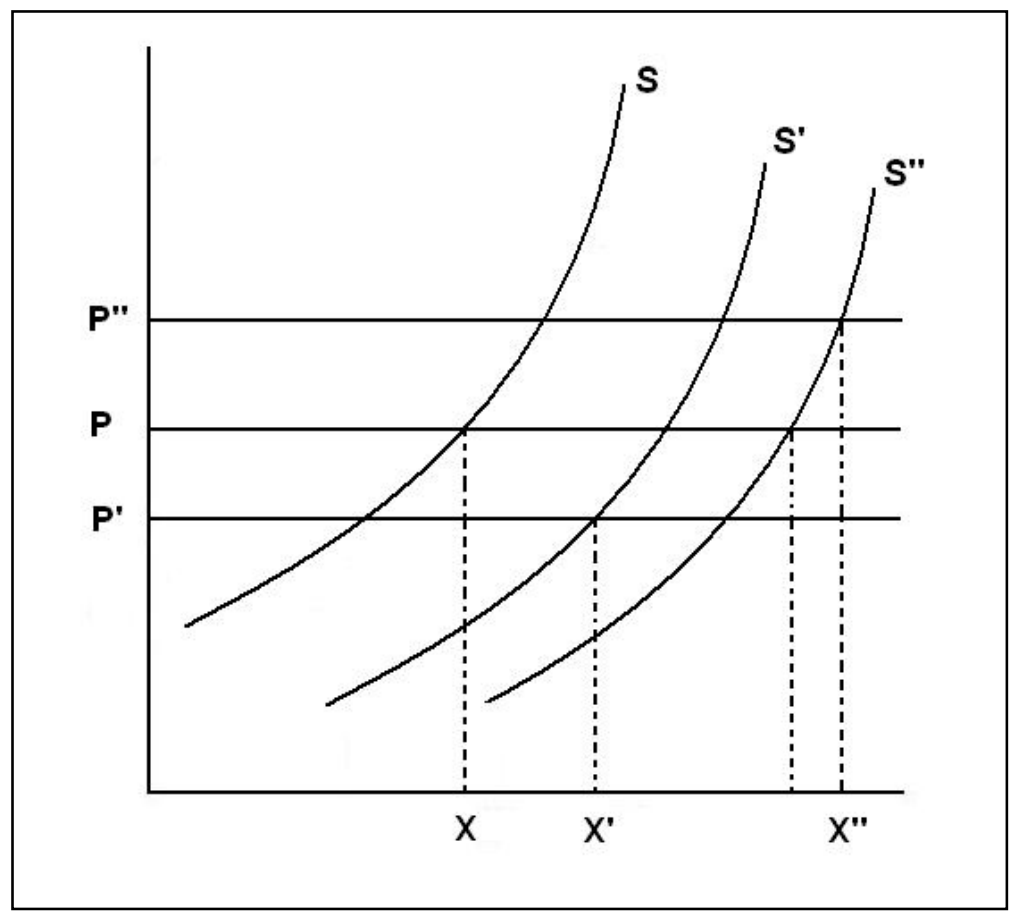

Figure 7B The Exogenous Export Price Hypothesis 
Figure 8 Real Exchange Rate Trends in Latin America 1870-1913 (1913=100)

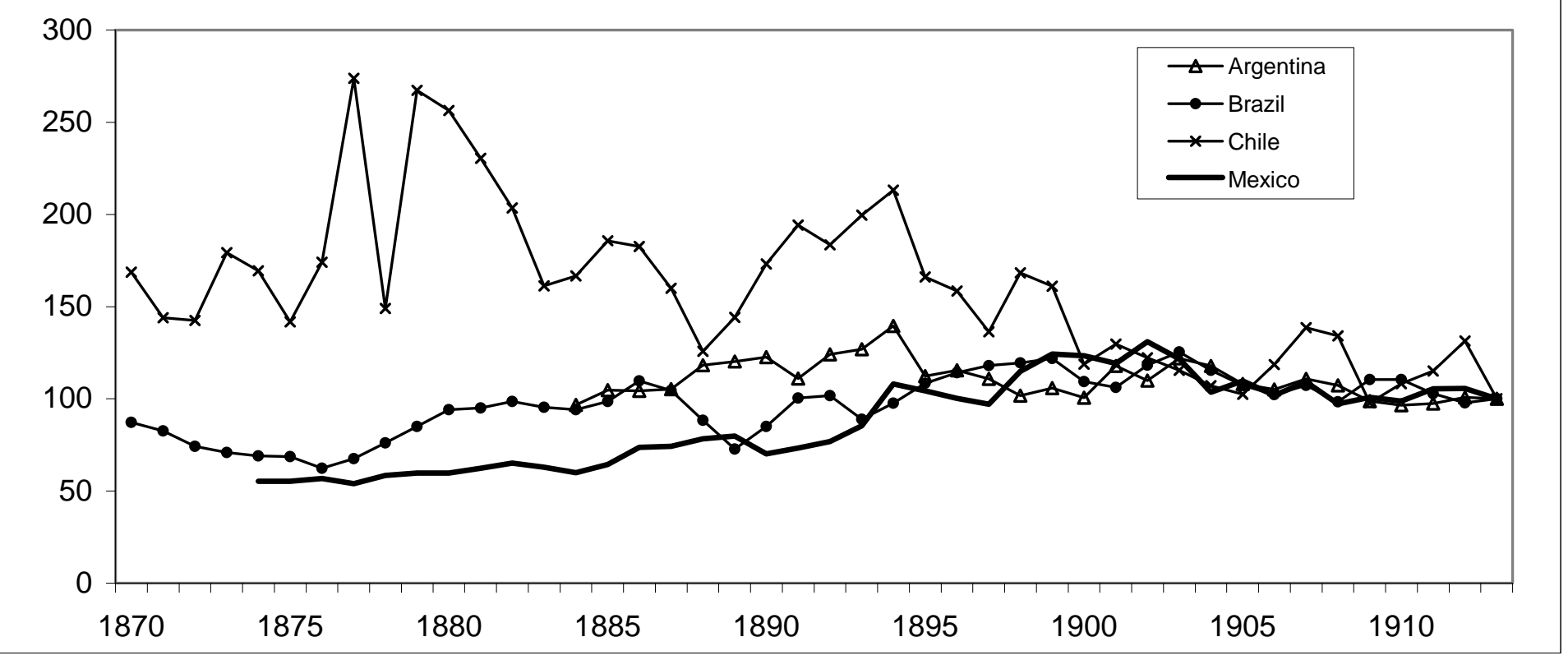

Notes: All nominal exchange rates (ER) are local currency relative to the US\$. Argentina. 


\section{Data Sources}

\section{Intermediate and capital goods imports}

United States: U.S. Department of Commerce and Labor, Bureau of Statistics (Treasury Department, Bureau of Statistics, before 1904), The Foreign Commerce and Navigation of the United States (annual 1870-1914; Washington, DC: USGPO). United Kingdom: Annual Statement of Trade of the United Kingdom with Foreign Countries and British Possessions, Parliamentary Papers (London: H.M.S.O, 18701914).

\section{Intermediate and capital goods import deflators}

Wholesale price indexes for historical comparisons, by commodity, editors of the Millennial ed., Susan B. Carter ... [et al.] Cambridge [England]; New York: Cambridge University Press, 2006. Table Ee 616. Dollar-sterling exchange rates: 1791-1914, Table Cc126. Wholesale price indexes for historical comparisons, by commodity group: 18601990 [Hanes], 1890-1914=100, all commodities other than farm products.

\section{Prices and Wages}

Nominal wages for all four countries from Jeffrey G. Williamson, "Real Wages, Inequality, and Globalization in Latin America Before 1940," Revista de Historia Economica, vol. 17, special number (1999), pp. 101-42, described in Williamson's website, AppLA_new wages.doc.

Argentina: Pa from food cost of living index, 1870-1881 from unpublished worksheets of Roberto Cortés Conde and 1882-1912 from Roberto Cortés Conde, El progreso Argentino 1880-1914 (Buenos Aires: Editorial Sudamericana, 1979), precio alimentos, p. 226, caudro 4.10, and 1913 from Williamson (1999), Appendix Table 1.2; Pm from Table 7.

Brazil: Pa and Pm from Luis Catão, "A New wholesale price index for Brazil during the period 1870-1913," Revista Brasileira Economia 1992 46(4): 519-33 (underlying data sent by the author).

Chile: w/cpi, cpi and Pm (implicit price deflator for imports) are taken from Juan Braun, Matias Braun, Ignacio Briones and Jose Diaz, "Economia Chilena 1810-1995:

Estadisticas Historicas," Documento de Trabajo No. 187 (Enero 2000), IEUC-Economia, pp. 101, 113 and 134. Pm deflator is taken to be the implicit price deflator for imports. Colombia: Pa based on food cost of living index from Alberto Pardo, Geografía Económia y Humana de Colombia (Bogotá: Ediciones Tercer Mundo, 1972); p. 221, Cuadro 107; pp. 234-5, Cuadro 110.

Mexico: Pa and Pm series calculated by the authors with data from: 1874-1884: El Correo del Comercio, La Colonia Española, El Minero Mexicano and La Escuela de Agricultura; 1885-1913: La Semana Mercantil. Food prices were weighted with shares from Memoria de Haciena 1909-10, pp.725-737 including rice, sugar, cocoa, coffee, chili, beans, wheat flour, corn, cheese and salt. Manufactured product prices were the 
average of yarn no. 20, coarse cloth, cashmeres, bed spread, sugar cane, brandy and soap. 1879 and 1881-1883 are interpolated.

Uruguay: $\mathrm{Pa}$ and Pm from correspondence with Luis Bértola.

United States: Nominal wage for the US is annual non-farm earnings of employed workers, from United States Historical Statistics (Washington, DC: USGPO, 1975), D780 and D735; Pm uses Warren-Pearson textile products 1870-1890 and BLS manufactured commodities 1890-1913, US Historical Statistics (1975), E56 and E89. US price level: US Historical Statistics (1975): E-183, FRB cost-of-living, p. 212.

\section{Net Barter Terms of Trade}

Argentina: C. Newland, Bulletin of Latin American Research 17 (1998). Chile: Juan Braun, Matias Braun, Ignacio Briones, Jose Diaz, Rolf Luders, and Gert Wagner, "Economia Chilena 1810-1995: Estadisticas Historicas," IEUC Documento de Trabajo 187 (Santiago: Pontificia Universidad Catolica de Chile, Eenero 2000), pp. 125128.

Latin America: L. Prados de la Escosura, "The Economic Consequences of Independence in Latin America," 2004 draft, prepared for Cambridge Economic History of Latin America Volume I, edited by Victor Bulmer-Thomas, John H. Coatsworth and Roberto Cortés Conde (Cambridge: Cambridge University Press, 2006).

Mexico: Pre-1879: R. Dobado González, A. Gómez Galvarriato, and J. G. Williamson, "Mexican Exceptionalism," Journal of Economic History 68 (September 2008). Post1878: Blattman-Clemens-Williamson database Venezuela: Caracas: Fundación Polar, 1997. Bases Cuantitativas de la Economía Venezolana: 1830-1995. Asdrúbal Baptista. C. Newland, Bulletin of Latin American Research 17 (1998).

\section{Real Exchange Rate:}

All nominal exchange rates (ER) are expressed as local currency relative to the US\$. Argentina: ER and price level from Alan Taylor, data underlying his "A Century of Purchasing-Power Parity," Review of Economics and Statistics 84, 1 (February 2002), pp. 139-50.

Brazil: Price level from Luis Catão, "A New wholesale price index for Brazil during the period 1870-1913," Revista Brasileira Economia 1992 46(4), pp. 519-33; ER from Heitor Moura Fikho, "Exchange rates of the mil-reis," MPRA Paper 5210, University of Munich (November 2007), pp. 16-17.

Chile: Real ER from Juan Braun, Mathias Braun, Ignacio Briones, and Jose Diaz, "Economia Chilena 1810-1995: Estadisticas Historicas," IEUC Documento de Trabajo 187 ((Santiago: Pontificia Universidad Catolica de Chile, Eenero 2000), p. 123. Mexico: Price level is the average of Pm and Pa. ER from INEGI, Estadísticas Históricas de México (Mexico: Instituto Nacional de Estadística, Geografía e Informática, 1986), p. 811. 
United States: Price level is the FRB cost-of-living index taken from United States Historical Statistics (Washington, DC: USGPO, 1975), E-183, p. 212. 